\title{
Healing Capacity of Leaves Stalks Extract of Pasak Bumi (Eurycoma longifolia Jack.) on Incised Wounds of Mice Skin
}

\author{
Ruqiah Ganda Putri Panjaitan ${ }^{1, *}$, Astrid Maulidya ${ }^{1}$, Anita Restu Puji Raharjeng ${ }^{2}$, Shovon Chakma ${ }^{3}$
}

Ruqiah Ganda Putri Panjaitan 1,*, Astrid Maulidya', Anita Restu Puji Raharjeng $^{2}$, Shovon Chakma ${ }^{3}$

'Department of Biology Education, Faculty of Teacher Training and Education, Tanjungpura University. Jl. Prof. Dr. H. Hadari Nawawi, Bansir Laut, Kec. Pontianak Tenggara, Kota Pontianak, West Kalimantan 78124, INDONESIA.

${ }^{2}$ Department Biology, UIN Raden Fatah Palembang, Jl. Prof. K. H. Zainal Abidin Fikri No. 1 Kel, Pahlawan, Kec. Kemuning, Kota Palembang, South Sumatera 30126, INDONESIA.

${ }^{3}$ School of Veterinary Science, University of Queensland, St Lucia QLD 4072, AUSTRALIA.

\section{Correspondence}

Ruqiah Ganda Putri Panjaitan

Department of Biology Education

Faculty of Teacher Training and Education,

Tanjungpura University, INDONESIA.

Phone no: +62 852-1150-7000,

E-mail: ruqiah.gpp@fkip.untan.ac.id

History

- Submission Date: 05-06-2020;

- Review completed: 15-07-2020;

- Accepted Date: 20-07-2020

DOI : 10.5530/pj.2020.12.186

Article Available online

http://www.phcogj.com/v12/i6

Copyright

(C) 2020 Phcogj.Com. This is an openaccess article distributed under the terms of the Creative Commons Attribution 4.0 International license.

\section{ABSTRACT}

Introduction: Pasak bumiis a medicinal plant commonly used as herbal medicine by Indonesian people. This study aims to examine the healing capacity of mice skin incised wounds by using pasak bumi leaves stalks ethanol extract ointment. Materials and Methods: This study used twenty-five male mice Balb/c strains, grouped into five groups, divided into three treatment groups (ointment with $20 \%$ extract concentration, ointment with $35 \%$ extract concentration, and ointment with $50 \%$ extract concentration), a positive control group using Betadine ${ }^{\circledR}$, and the negative the negative control group using an ointment base. The back of the mouse was slashed $1.0 \mathrm{~cm}$ long with a depth of $0.2 \mathrm{~cm}$. Then, the wound was smeared twice a day for 21 consecutive days. Results: The application of $20 \%, 35 \%$, and $50 \%$ of ointment extract had the effect of healing the incised wounds after 21 days just as Betadine ${ }^{\circledR}$. From the description score of the wound on the twenty-first day, it can be seen that the applied ointment with $35 \%$ of extract concentration shows the same healing capacity as Betadine ${ }^{\circledast}(p>0.05)$, unlike the administration of ointment base $(p<0.05)$. Conclusions: It can be concluded that pasak bumi leaves stalks has the potential effect to heal incised wounds.

Key words: Eurycoma longifolia Jack., Incised wound, Ointment.

\section{INTRODUCTION}

Wounds are the effect of tissue damage to the skin caused by contact with heat sources (such as chemicals, hot water, fire, radiation, and electricity), as the result of medical action or a change in physiological conditions. ${ }^{1}$ Based on the mechanism, there are six types of wounds: incised wounds, contusion wounds, broken wounds, leakage wounds, scars, and burns. Incised wounds are cuts caused by sharp-edged instruments. A contusion wound is the type of injury caused by a collision of the body with a blunt object which causes damage to the internal part of the body. A broken wound is the type of wound that has irregular, jagged contours and is quite deep. A leakage wound is a type of wound that causes a small hole in the surface of the skin but penetrates the body deeply. A scar is a type of wound which is not too deep but has a very wide wound surface and generally comes from the scratching of the skin on a rough surface. A burn is a type of injury caused by the burning of body parts. ${ }^{2}$ Injuries are a torn condition or a tearing of tissue in the body, whether it is on the skin, muscles, nerves, blood vessels, or lymph. There are various causes of injuries; among them are accidents, operations, radiation, electric shoch, and chemicals. ${ }^{2-5}$ The wound healing process involves many cells in the body, through the stages of inflammation, proliferation, and maturation. Inflammatory stages begin at the time of injury and last up to two to three days, and if there is no infection in the inflammatory phase, the wound healing process will enter the proliferative stage. The proliferative stage starts on the second or third day and lasts until the third week. The next stage is maturation; this stage requires the longest time in wound healing. ${ }^{6}$

Several factors that influence the wound healing process are age, nutrition, infection, hematoma, ischemia, diabetes, wound condition, and medication. ${ }^{3}$ Infection is an inhibiting factor in wound healing because it can cause inflammation and tissue damage. The signs of the inflammatory process are erythema (redness), oedema (swelling), heat, and the presence of pain. ${ }^{4}$

Damage to the outer surface of the body will be the entry point for foreign objects. ${ }^{2}$ Therefore, an attempt is necessary for the body to heal wounds. ${ }^{5}$ According to Maryunani ${ }^{3}$, the wound healing process is divided into three phases: inflammation, proliferation, and and maturation. The inflammatory phase is characterized by an increase in blood flow to the wound area and is followed by an increase in fibrin flow and white blood cells that work to eat microorganisms and dead cells. The proliferative phase is characterized by the formation of wound healing layers, and the final phase in maturation is characterized by a more apparent wound healing, resembles tissue and unification of the new collagen and suppresses the blood vessel that causes the wound to be flat and thin. Correspondingly, the result of the research showed that after five days, the wound would experience healing which was characterized by the formation of a scab that covers the entire wound area. This healing time is faster than normal because the wound is smeared with tapak dara leaf. ${ }^{6}$

Pasak bumi is one of the native plants of Indonesia. Traditionally, all parts of this plant are being used as a herbal medicine. The pasak bumi root is commonly 
used as an aphrodisiac, but it is also used to treat dysentery, fever, and malaria. The bark and stems of the pasak bumi are useful to treat a fever, cancer sores, intestinal worms, bone pain, and tonic after childbirth. The leaves of the pasak bumi are useful for streating itching, while the flowers and fruits are used to treat headaches, abdominal pain, and bone pain. ${ }^{7}$

In addition, the stem of pasak bumi in medicine serves as a natural aphrodisiac for men. ${ }^{8}$ Moreover, the roots of pasak bumi have also been scientifically tested as an anti-malarial, ${ }^{9-13}$ anti-bacterial, ${ }^{14}$ cytotoxic, ${ }^{12}$ anti-osteoporosis, ${ }^{15,16}$ anti-oxidants, and anti-inflammatory, ${ }^{17}$ hepatoprotector, ${ }^{18}$ and is also safe on the liver organ of lactating mice, ${ }^{19}$ while maintaining the physiological conditions of the lactating mice. ${ }^{20}$

The pasak bumi root contains various compounds including the canthin6-one alkaloid, alkaloid $\beta$-carboline, ${ }^{11-12}$ quassinoids, ${ }^{12-21}$ triterpenic tirucallane-type, ${ }^{12}$ biphenylneolignan, ${ }^{12}$ and squalene derivatives. ${ }^{12,23} \mathrm{In}$ connection with various potentials of pasak bumi roots, especially as an anti-inflammatory agent together with its various compounds, there are possibilities that other parts of this plant, especially the petiole, also have potential as medicine.

The investigative study of pasak bumi leaf stalks in medicine has not yet been reported. Some plants that were reported to have efficacy as incised wound healers are Aloe vera leaves, ${ }^{24}$ pisang ambon pseudostem, ${ }^{25}$ and binahong leaves. ${ }^{26}$ Furthermore, the result of phytochemical studies shows that Aloe vera leaves contain alkaloids, flavonoids, and steroids. ${ }^{27}$ The pisang ambon tree stems were reported to contain saponins, anthraquinones, quinones, and lignin. ${ }^{25}$ While binahong leaf stems contain alkaloids compounds, flavonoids, and tannins. ${ }^{28}$ Based on the above description, this study was conducted to examine the activity of incised wound healing capacity of pasak bumi (Eurycoma longifolia Jack.) leaves stalks ethanol extract.

\section{MATERIALS AND METHODS}

\section{Animal and ethical approval}

The experimental animals used were 25 male Balb/c mice aged 2-3 months with body weight ranging from 22-34 grams. Before treatment started, the animals were acclimatized for seven consecutive days by being fed and given water in ad libitum. The use of experimental animals in this test is under the ethical feasibility number 91 / II / HREC / 2018 issued by Sebelas Maret University in the Faculty of Veterinary Medicine, Indonesia.

\section{Extraction}

A total of 600 grams of pasak bumi leaves stalks including the stems and leaves were obtained from Sulai forest and Sungai Keras forest in Mensasak Hamlet, Hulu Gurung Subdistrict, Kapuas Hulu Regency and in Gunung Peramas, Kayong Utara Regency. The pasak bumi leaves stalks were cleaned was cleaned and then dried, then extracted by maceration using $70 \%$ ethanol. The maceration process refers to Harborne. $^{29}$ Maceration was carried out for $3 \times 24$ hours twice. The resulting filtrate was evaporated, and a product of 16.76 grams was obtained.

\section{Qualitative phytochemical test}

Qualitative phytochemical tests carried out refer to Harborne. ${ }^{30}$ Phytochemical test results were reported by the Chemistry Laboratory of the Faculty of Mathematics and Natural Sciences, Tanjungpura University, Pontianak on certificate No. 038 / LABKIM / XII / 2017.

\section{Ointment making}

The formula used in making the ointment base refers to Agoes: ${ }^{31}$

$\begin{array}{ll}\text { Adeps lanae } & : 15 \mathrm{~g} \\ \text { Vaseline album } & : 85 \mathrm{~g} \\ \text { m.f. ointment } & : 100 \mathrm{~g}\end{array}$

The formulation of the ointment:

a) Formulation of pasak bumi leaves stalks ethanol extract ointment $20 \%$

$\begin{array}{ll}\text { Extract } & : 1 \mathrm{~g} \\ \text { Ointment base } & : 4 \mathrm{~g} \\ \text { m.f. ointment } & : 5 \mathrm{~g}\end{array}$

b) Formulation of pasak bumi leaves stalks ethanol extract ointment $35 \%$

$\begin{array}{ll}\text { Extract } & : 1.75 \mathrm{~g} \\ \text { Ointment base } & : 3.25 \mathrm{~g} \\ \text { m.f. ointment } & : 5 \mathrm{~g}\end{array}$

c) Formulation of pasak bumi leaves stalks ethanol extract ointment $50 \%$

$\begin{array}{ll}\text { Extract } & : 2.5 \mathrm{~g} \\ \text { Ointment base } & : 2.5 \mathrm{~g} \\ \text { m.f. ointment } & : 5 \mathrm{~g}\end{array}$

m.f. ointment $\quad: 5 \mathrm{~g}$

The healing capacity of pasak bumi leaves stalks ethanol extract on incised wounds

Mice were taken randomly and divided into five groups, where each group consisted of five animals. The hair on the back area was shaved and removed, and then the back area was cleaned with $70 \%$ alcoholic cotton, then the cut was done along $1 \mathrm{~cm}$ with a depth of $0.2 \mathrm{~cm}$. The day the wound was made was stated as the first day. Furthermore, the wound in the first group (the positive control group) was smeared with Betadine, the second group was smeared with an ointment base (negative control group), and the third group was smeared with pasak bumi leaves stalks ethanol extract ointment (extract concentrations of $25 \%, 35 \%$ and $50 \%$ ). The ointment was applied by applying a thin layer evenly on the surface of the wound. Basting was done twice a day at 08.00 a.m and 02.00 p.m for 21 days. During those days, observations and scores were determined based on the description of the wounds from each individual.

\section{Data analysis}

This study used a completely randomized design. Wound scores on the second, fourth, seventh, fourteenth, and twenty-first days were statistically analyzed and if they were significantly different $(\mathrm{p}<0.05)$ followed by Duncan's test. Data analysis was performed using SPSS version 25.

\section{RESULTS AND DISCUSSION}

There were some limitations on this research including the wound that tested is only the wound that is made by the procedures, the pasak bumi ointment made are limited to the concentration as made; and the observation is limited to descriptive only. Regarding the time needed for the wound healing, the results of this study indicate that by applying pasak bumi leaves stalks ethanol extract ointment requires a shorter time for healing. Moreover, pasak bumi leaves stalks ethanol extract ointment has a similar healing capacity to cure incised wounds as well as Betadine ${ }^{\circledast}$ (Figure 1., Table 1., and Table 2.). 


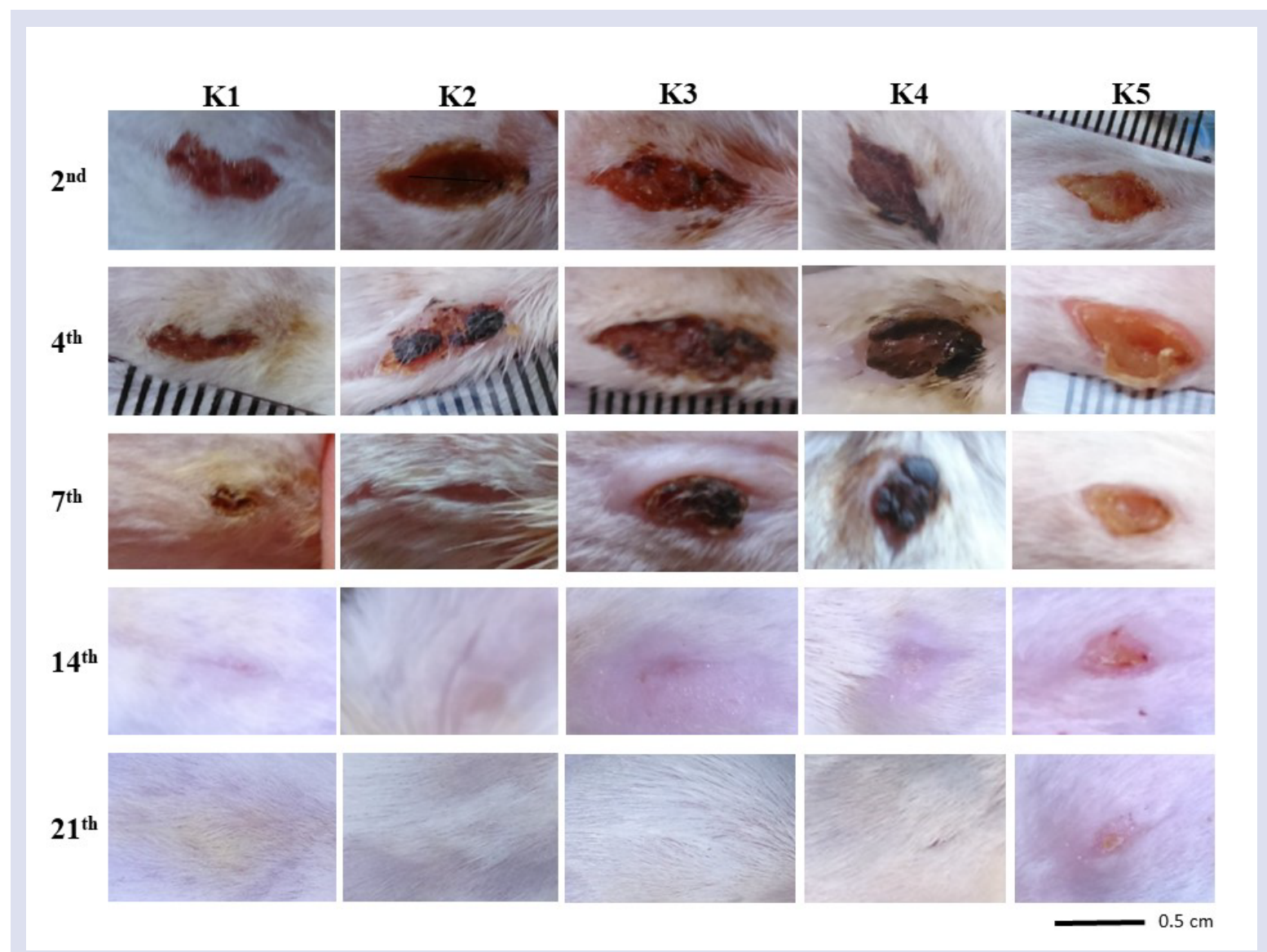

Figure 1: Changes of incised wound based on the $2^{\text {nd }}, 4^{\text {th }}, 7^{\text {th }}, 14^{\text {th }}$ and $21^{\text {st }}$ day.

Table 1: Incised Wound Scores.

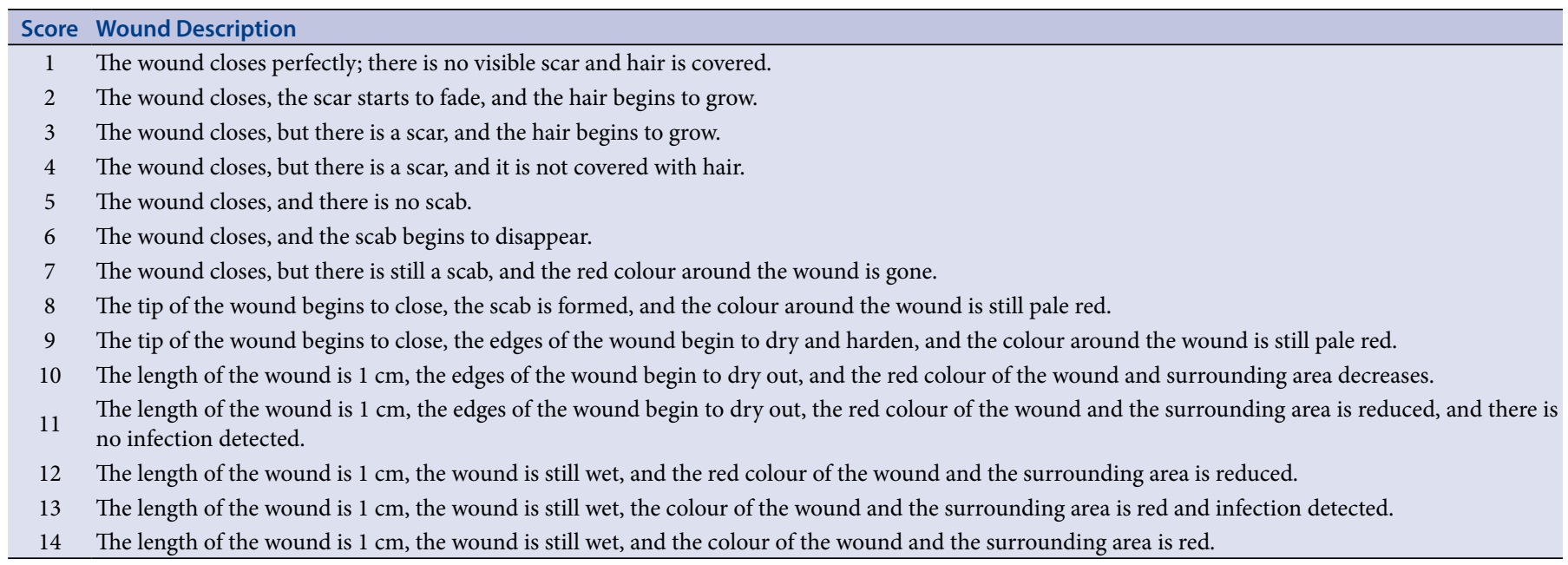

Table 2: Average score of incised wound based on the description of the wound. Observations were made on the $2^{\text {nd }}, 4^{\text {th }}, 7^{\text {th }}, 14^{\text {th }}$ and $21^{\text {st }}$ day.

\begin{tabular}{cccccc}
\hline Day- & K1 & K2 & K3 & K4 & K5 \\
\hline 2 & $14.00^{\mathrm{a}} \pm 0.00$ & $12.00^{\mathrm{a}} \pm 0.00$ & $11.60^{\mathrm{a}} \pm 0.89$ & $10.80^{\mathrm{b}} \pm 1.09$ & $12.40^{\mathrm{a}} \pm 0.54$ \\
4 & $10.00^{\mathrm{b}} \pm 0.00$ & $11.60^{\mathrm{a}} \pm 0.89$ & $10.40^{\mathrm{b}} \pm 0.89$ & $10.40^{\mathrm{b}} \pm 0.89$ & $10.60^{\mathrm{b}} \pm 0.54$ \\
7 & $9.40^{\mathrm{a}} \pm 0.54$ & $9.40^{\mathrm{a}} \pm 1.94$ & $9.60^{\mathrm{a}} \pm 0.54$ & $8.80^{\mathrm{a}} \pm 0.83$ & $9.40^{\mathrm{a}} \pm 0.54$ \\
14 & $4.80^{\mathrm{b}} \pm 1.09$ & $5.50^{\mathrm{b}} \pm 1.91$ & $4.00^{\mathrm{b}} \pm 0.00$ & $4.00^{\mathrm{b}} \pm 1.41$ & $7.80^{\mathrm{a}} \pm 0.44$ \\
21 & $1.20^{\mathrm{b}} \pm 0.44$ & $1.50^{\mathrm{b}} \pm 0.57$ & $1.20^{\mathrm{b}} \pm 0.44$ & $1.40^{\mathrm{b}} \pm 0.54$ & $3.80^{\mathrm{a}} \pm 1.48$ \\
\hline
\end{tabular}

Different letters on the same line show significant differences in the Duncan test $(\mathrm{p}<0.05)$. ${ }^{*}$ The number shown after the symbol \pm shows the standard deviation (SD) value. K1: Betadine ${ }^{\circ}$ K2: pasak bumi leaves stalks ethanol extract ointment 20\%; K3: pasak bumi leaves stalks ethanol extract ointment 35\%; K4: pasak bumi leaves stalks ethanol extract ointment 50\%; K5: ointment base. 
From the results of observation and scoring, it was known that on the second day, the condition of the wound in each treatment group was varied. Even though overall observation showed that the wound was still red and had not closed, the wound score was still high. However, compared to other groups, the condition of the wounds for groups in which the researchers applied the pasak bumi leaves stalks ethanol extract ointment $20 \%, 35 \%$, and $50 \%$ was more improved; even the condition of the wounds on the application of pasak bumi leaves stalks ethanol extract ointment had reached the best result $(\mathrm{p}<0.05)$. While the observation on the fourth day showed the wound had begun to dry and the red color on the wound had begun to decrease, on the contrary, in the group with the administration of the extract pasak bumi leaf stalks ethanol $20 \%$ was still wet around the wound $(\mathrm{p}<0.05)$. This is in line with the opinion of Maryunani ${ }^{3}$ who said that the inflammatory process begins after surgery and ends on the third day or sometimes the fourth day and Sewta et al.$^{24}$ who states that by giving Aloe vera leaf extract on the third day the wound begins to dry out and the length of the wound is also reduced.

The observation on the seventh day showed that the condition of the wound in the whole group was improved and it was marked by the tip of the wound, which began to close, the edge of the wound had begun to dry and harden, and the colour around the wound was pale red. Furthermore, observation on the fourteenth day showed that wounds cured by Betadine and the pasak bumi leaves stalks ethanol extract had closed while the scab had disappeared; otherwise, the wound with the ointment base was still marked by scab and pale red around the wound. In line with the result of research by Sewta et al. ${ }^{24}$ on the fourteenth day after the wound was given the aloe vera leaf extract, it had closed properly. According to Kanazawa et al. ${ }^{32}$ on the fourth, seventh, and fourteenth day, the wound healing process began to enter the proliferative stage. This stage is the stage of tissue formation and wound closure.

Furthermore, Dewi et al. ${ }^{6}$ stated that the process of granular tissue formation is a mark of healing, and this process starts from the bottom of the wound. The tissue formation begins with the growth of capillaries, and this granulation process goes along with the re-epithelialization process. In the final stage of this process, an epithelialization process will occur on the wound surface, and the wound will develop into a scab that consists of plasma and prodeni which mixes with dead cells. Moreover, Harvey ${ }^{33}$ states that the re-epithelialization process shows the phase when the wound has been closed by epithelial cells. Macrophages release epidermal growth factors that will stimulate the proliferation and migration of epithelial cells. Epithelial cells can only move up the active tissue and require a moist environment. Regarding humidity regulation, Yanhendri ${ }^{34}$ stated that to preserve the wound from infection and to moisturize the skin, the ointment can be used as a semisolid preparation made from fat, which is often used for local treatment of the skin.

The result of observation on the twenty-first day showed that wound healing began to enter the maturation or matured stage. The condition of the wound in the group with the administration of Betadine ${ }^{\diamond}$ and pasak bumi leaves stalks ethanol extract had closed correctly, there were no scars and the skin had been covered with hair. The group with the ointment base had closed, but there was still a scar and the hair just began to grow $(\mathrm{p}<0,05)$. Dewi et al. ${ }^{6}$ stated that at the maturation stage, collagen bonding occurs to preserve scar tissue and the epithelialization process also happens to coat the skin. Furthermore, Maryunani ${ }^{35}$ added that the maturation stage is the last phase and a long phase for the process of wound healing. At the maturation stage, collagen fibbers will increase gradually and will get thicker. Increased collagen fibbers will cause the number of leukocytes to return to the normal range. Furthermore, collagen fibbers will spread by bonding together gradually to support tissue recovery.
Overall, from the results of this study, it was found that pasak bumi leaves stalks ethanol extract have anti-inflammatory capacity while healing wounds. This capacity is assumed to be related to the content of alkaloids, terpenoids, saponins, tannins, and phenols in the pasak bumi leaves stalks ethanol extract. As a result of previous studies, Kimura et al. ${ }^{36}$ reported that saponin compounds could trigger Vascular Endothelial Growth Factor (VEGF) and increase the number of macrophages to migrate to the wound area. This process can increase the production of cytokines to activate fibroblasts in wound tissue. In addition, Kamboj and Saluja ${ }^{37}$ and Hidayati and Harjono ${ }^{38}$ each reported that terpenoid and alkaloid act as anti-bacterial. In addition, Ashok and Upadhyaya ${ }^{39}$ stated that tannins act as astringents, substances that are useful for shrinking the wound so that bleeding can stop faster and the wound dries more quicker. The tannin, terpenoid, and alkaloid compounds act as an astringent or as a bleeding stopper, overcoming the inflammation, accelerating wound healing and increasing new tissue regeneration ${ }^{40}$ while phenol plays a role in helping wound healing process with collagen formation. ${ }^{41}$ In the near future, we would try to explore the other part of this plant to find its function as a wound-healing agent.

\section{CONCLUSION}

The conclusion of this research the pasak bumi leaves stalks ethanol extract ointment $35 \%$ has proven to have the best healing capacity for the incised wound, in comparison to another composition of extract, and it is similar to the Betadine as a positive control,

\section{ACKNOWLEDGEMENTS}

The authors thank The Center of Food and Nutrition, Gadjah Mada University, Yogyakarta for facilitated this research.

\section{CONFLICTS OF INTEREST}

The authors declare that they have no conflicts of interest.

\section{REFERENCES}

1. Purnama, H., Sriwidodo, Ratnawulan, S. (2017) Review Sistematik: Proses penyembuhan dan perawatan luka. Farmaka, 15(2):251-258

2. Abdurrahmat, A. S. (2014) Luka peradangan dan pemulihan. J ENTROPI, $9(1): 729-738$

3. Maryunani, A. (2014) Perawatan Luka Seksio Caesarea (SC) dan Luka Kebidanan Terkini (dengan Penekanan "Moist Wound Healing". Bogor: IN MEDIA.

4. Suwiti, N. K. (2010) The histological detection of skin wound after treatment with mengkudu leaves (Morinda citrifolia Linn.). Buletin Veteriner Udayana, 2(1):1-9.

5. Gou, S. and DiPietro, L. A. (2010) Factors affecting wound healing. J. Dent Res., 89(3):219-229.

6. Dewi, I. A. L. P. Damriyasa, I. M. and Dada, I. K. A. (2013) Bioaktivitas ekstrak daun tapak dara (Catharanthus roseus) terhadap periode epitelisasi dalam proses penyembuhan luka pada tikus wistar. Indonesia Medicus Veterinus, 2(1):58-75.

7. Hadad, E.A. and Taryono, M. (1998) Pasak Bumi Eurycoma longifolia Jack In: Supriadi. Tumbuhan Obat, Khasiat dan Penggunaannya. Jakarta: Penerbit Pustaka Indonesia.

8. Ang, H. H., Ngai, T. H. and Tan, T. H. (2003) Effect of Eurycoma longfolia Jack on sexual qualities in middle aged male rats. Phytomedicine, 10(6-7):590-593.

9. Ang, H. H., Chan, K. L. and Mak, J. W. (1995) In vitro anti-malarial activity of quassinoids from Eurycoma longifolia against Malaysian chloroquine-resistant Plasmodium falcifarum isolates. Planta Med., 61(2):177-1178.

10. Satayavivad, J., Soonthornchareonnon, N., Somanaban, A. and Thebtaranonth, Y. (1998) Toxicological and anti-malarial activity of eurycomalactone and Eurycoma longifolia extract in mice. Thai J. Phytopharm., 5(2):1-20.

11. Chan, K. L., Choo, C. Y., Abdullah, N. R. and Ismail, Z. (2004) Antiplasmodial studies of Eurycoma longifolia Jack using the lactate dehydrogenase assay of Plasmodium falciparum. J Ethnopharmacol, 92:223-227.

12. Kuo, P. C., Damu, A. G., Lee, K. H. and Wu, T. S. (2004) Cytotoxic and antimalarial constituents from the roots of Eurycoma longifolia. Bioorg. Med Chem., 12(3):537-544. 
13. Yusuf H, Mustofa, Wijayanti MA, Susidarti RA, Asih PBS, Suryawati, et al. (2013) A new quassinoid of four isolated compounds from extract Eurycoma longifolia Jack. roots and their in-vitro anti-malarial activity. Int. J. Res. Pharm. Biomed. Sci., 4(3):728-73.

14. Danial, M., Saghal, G., Mubbarakh, S. A., Sundarasekar, J. and Subramaniam, S. (2013) Anti-bacterial studies on in vivo plant parts of medicinally important Eurycoma longifolia (tongkat ali). Pak. J. Bot., 45(5):1693-1700.

15. Effendy, N. M., Mohamed, N., Muhammad, N., Mohamad, I. N. and Shuid, A. N. (2012) Eurycoma longifolia: medicinal plant in the prevention and treatment of male osteoporosis due to androgen deficiency. Evid. Based Complement. Altern. Med., 12:1-9.

16. Razak, H. S. A., Shuid, A. N. and Mohamed, I. N. (2012) Combined effects of Eurycoma longifolia and testosterone on androgen-deficient osteoporosis in a male rat model. Evid. Based Complement Alternat. Med., 12:1-6.

17. Varghese, C. P., Ambrose, C., Jin, S. C., Lim, Y.J. and Keisaban, T. (2013) Antioxidant an anti-inflammatory activity of Eurycoma longifolia Jack, A traditional medicinal plant in Malaysia. Int. J. Pharm. Sci. Nanotech., 5(4):1875-1878.

18. Panjaitan, R. G. P., Handharyani, E., Chairul and Manalu, W. (2013) Hepatoprotective activity of Eurycoma longifolia Jack. roots. Indian J. Tradit. Know., 12(2):225-230.

19. Panjaitan, R. G. P. (2017) Serum enzymes activity and liver histopathological changes of lactating mice treated with Eurycoma longifolia Jack. roots. Indian J. Tradit. Know., 16(4):593-597.

20. Panjaitan, R. G. P. and Zulfan. (2015) The effect of administration of pasak bumi (Eurycoma longifolia Jack.) roots to haematological profile of lactating mice. Indian J. Tradit. Know., 14(2):231-235.

21. Ang, H. H., Hitotsuyanagi, Y., Takeya, K. and Eurycolactones, A-C.(2000) Novel quassinoids from Eurycoma longifolia. Tetrahedron Lett., 41:6849-6853.

22. Bedir, E., Abou-Gazar, H., Ngwendson, J. N. and Khan, I. A. (2003) Eurycomaoside: a new quassinoidtype glycoside from the roots of Eurycoma longifolia. Chem. Pharm. Bull., 51(11):1301-1303.

23. Morita, H., Kishi, E., Takeya, K., Itokawa, H. and litaka, Y. (1993) Squalene derivatives from Eurycoma longifolia. Phytochem., 34(3):765-771.

24. Sewta, C. A., Mambo, C. and Wuisan, J. (2015) Uji efek ekstrak daun lidah buaya (Aloe vera L.) terhadap penyembuhan luka insisi kulit kelinci (Oryctolagus cuniculus). J e-Biomedik (eBm), 3(1):453-459.

25. Prasetyo, B.F., Wientarsih, I. and Priosoeryanto, B. P. (2012) Activity of Ambon banana extract in gel formulation on the wound healing process of mice skin. J Veteriner;11(2):70-73.
26. Pebri, I. G., Rinidar and Amiruddin. (2017) Pengaruh pemberian ekstrak daun binahong (Anredera cordifolia) terhadap proses penyembuhan luka insisi (Vulnus incisivum) pada mencit (Mus muculus). JIMVET, 2(1):1-11.

27. Kasmawati, H., Suryani and Mutmainna. (2015) Efek antihiperglikemik ekstrak etanol daun lidah buaya (Aloe vera Linn) dan ekstrak etanol daun sambiloto (Andrographis paniculata Nees) serta kombinasinya pada mencit jantan (Mus musculus). Majalah Farmasi, Sains, dan Kesehatan, 1(2):5-9.

28. Parwati, N. K. F, Napitupulu, M. and Diah, A. W. M. (2014) Uji aktivitas antioksidan ekstrak daun binahong (Anredera cordifolia (Tenore) Steenis). J. Akad. Kim., 3(4):206-213.

29. Harborne, A. J. (1998) Phytochemical methods a guide to modern techniques of plant analysis. London: Springer Science \& Business Media.

30. Harborne, J. B. (1987) Metode Fitokimia. Penuntun Cara Modern Menganalisis Tumbuhan. (eds: Padmawinata, K). Bandung: Penerbit ITB.

31. Agoes, G. (2014) Peracikan dan Penyaluran Obat (SFI-8). Bandung: Penerbit ITB.

32. Kanazawa, S., Fujiwara, T., Matsuzaki, S., Shingaki, K., Taniguchi, M., Miyata, S., et al. (2010) bFGF regulates PI3-kinase-rac1-JNK pathway and promotes fibroblasts migration in wound healing. PloS One, 5(8):1-12.

33. Harvey, C. (2005) Wound Healing. Orthopaedic Nursing, 24(2):143-159.

34. Yanhendri and Yenny, S. W. (2012) Berbagai bentuk sediaan topikal dalam dermatologi. CDK, 39(6):423-430.

35. Maryunani, A. (2015) Perawatan Luka Modern (Modern Woundcare) Terkini dan Terlengkap, Bogor: IN MEDIA.

36. Kimura, Y., Sumiyoshi, M., Kawahira, K. and Sakanaka, M. (2006) Effects of ginseng saponins isolated from red ginseng roots on burn wound healing in mice. British J. Pharm., 148(6):860-870.

37. Kamboj, A. and Saluja, A. K. (2008) Ageratum conyzoides L.: A review on its phytochemical and pharmacological profile. International J. Green Pharm., 2008:59-68.

38. Hidayati, A. S. and Harjono. (2017) Uji aktivitas antibakteri krim ekstrak daun babadotan (Ageratum conyzoides. L) dalam pelarut etanol. J. MIPA, 40(1):3338.

39. Ashok, P. K. and Upadhyaya, K. (2012) Tannins are astringent. J. Pharmacogn Phytochem., 1(3):45-50.

40. Reddy, K., Srinivas, A., Sanjeeva, K. and Ganapaty, S. (2011) Evaluation of Hypoglicemic and wound healing activities of Lantana Wightiana wall ex. Gamble leaves. Int. Res. J. Pharm., 2(12):264-266.

41. Victor, W., Wong, M. D., Geoffrey, C., Gurtner, M. D., Michael, T., Longaker, M D., MBA. (2013) Wound Healing: A Paradigm for Regeneration. Symposium on Regenerative Medicine 88(9):1022-1031.

\section{GRAPHICAL ABSTRACT}

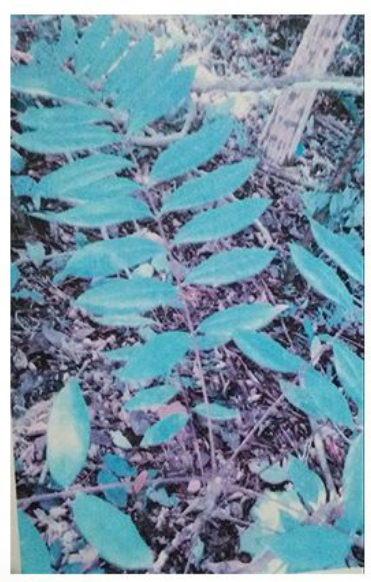

Pasak Bumi (Eurycoma longifolia jack.)

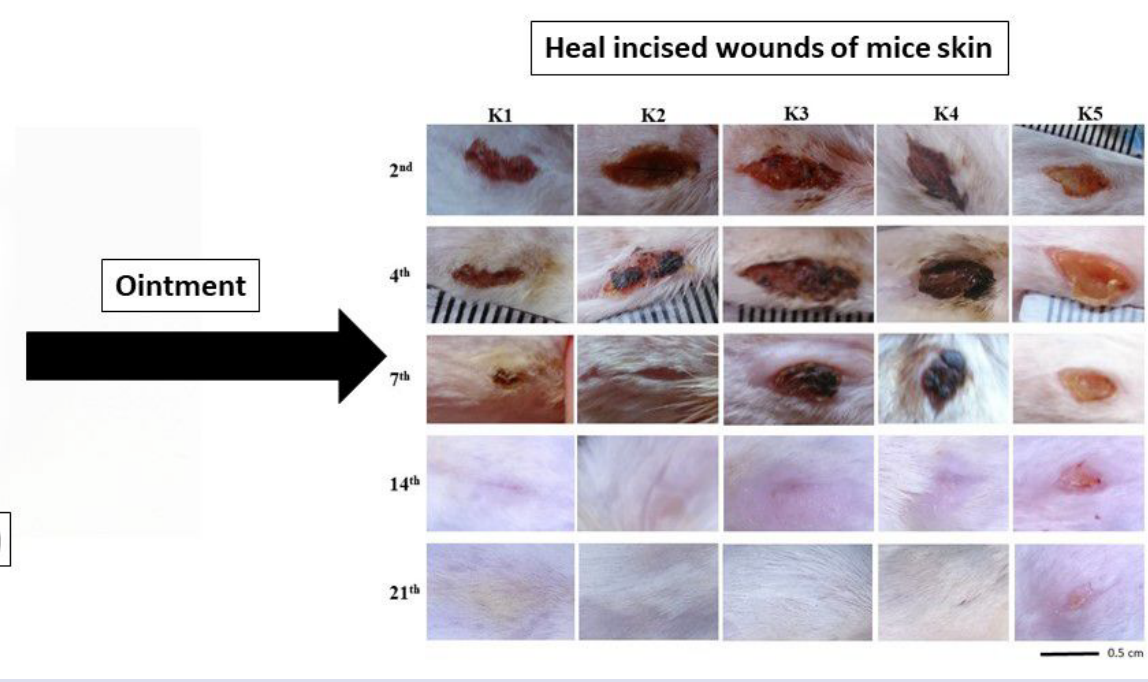




\section{ABOUT AUTHORS}

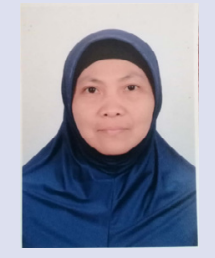

Ruqiah Ganda Putri Panjaitan, graduated from the Department of Biology, FMIPA Andalas University, Padang. She got her masters and doctorates from the Department of Biology FMIPA Bogor Agricultural University. Her field of interest is the study of medicinal plant activity. Now, she is working as a lecturer in Tanjungpura University.



Astrid Maulidya, completed her bachelor's degree in biology education study program, FKIP, Tanjungpura University, Pontianak-Indonesia. The title of her thesis is "The Feasibility of Flash Media Submaterial Flashbook Media Class XI SMA Through the Test of The Influence of Pasak Bumi leaves stalks extract (Eurycoma longifolia Jack.) on The Healing Power of Mice Skin Incision Wounds".

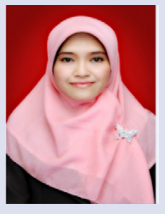

Anita Restu Puji Raharjeng, completed her bachelor degree from Biology, Faculty of Mathematics and Science, State University of Malang. She got two master degree from Biology, Brawijaya University and Biomedical Science, James Cook University. Now she is taking PhD in Biology, Gadjah Mada University, and her research project is about The Potention of Dioscorea alata Linn for Diabetes Mellitus Therapy and its effect on the histological structure of Pancreas and Intestine of Zebrafish (Danio rerio). Prior continuing her PhD, she is working is UIN Raden Fatah Palembang, as a lecturer.

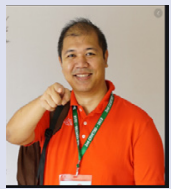

Shovon Chakma is a veterinarian from Bangladesh with an over four years of experience working in infectious disease surveillance programs in Bangladesh. He completed One Health Epidemiology Fellowship from Massey University, New Zealand in 2016 and is a life member of One Health Bangladesh. He implemented the first known study of zoonotic agents carried by non-indigenous rodents living in the Australian wettropical forest interface. His PhD project will evaluate the risk of live bird market environmental contamination heterogeneity with avian influenza over space and time in Bangladesh, which will then be linked to health outcomes in poultry and humans.

Cite this article: Panjaitan RGP, Maulidya A, Raharjeng ARP, Chakma S. Healing Capacity of Leaves Stalks Extract of Pasak Bumi (Eurycoma longifolia Jack.) on Incised Wounds of Mice Skin. Pharmacogn J. 2020;12(6):1351-6. 